\title{
Perspectives on Energy Insecurity and Its Impacts on Urban Livelihoods: Adaptation and Resilience of Women in the Informal Sector
}

OPEN ACCESS

Edited by:

Caitlin Robinson,

University of Liverpool,

United Kingdom

Reviewed by:

Neil Simcock

Liverpool John Moores University,

United Kingdom

Nathalie Ortar

UMR5593 Laboratoire Aménagement,

Économie, Transport (LAET), France

${ }^{*}$ Correspondence:

Memory Reid

400526@students.wits.ac.za

Specialty section: This article was submitted to

Urban Energy End-Use,

a section of the journal

Frontiers in Sustainable Cities

Received: 24 May 2021 Accepted: 07 September 2021

Published: 13 October 2021

Citation:

Reid M and Simatele MD (2021) Perspectives on Energy Insecurity and

Its Impacts on Urban Livelihoods:

Adaptation and Resilience of Women

in the Informal Sector.

Front. Sustain. Cities 3:706476. doi: 10.3389/frsc.2021.706476

\author{
Memory Reid ${ }^{1 *}$ and Mulala Danny Simatele ${ }^{1,2}$ \\ ${ }^{1}$ School of Geography, Archaeology and Environmental Studies, University of the Witwatersrand, Johannesburg, South \\ Africa, ${ }^{2}$ The Global Change Institute, University of the Witwatersrand, Johannesburg, South Africa
}

Variability in temperature and precipitation due to climate change is predicted to significantly impact on Southern African countries' resources. These variations have the potential to affect the energy sector due to a heavy reliance on hydropower for electricity in the region. Energy insecurity is largely felt in cities as they are large consumers of the resource. This negatively impacts on urban livelihoods reliant on electricity like those in the informal sector. A survey of electricity dependent home-based informal businesses operated by women was conducted, to generate information on the vulnerability of urban livelihoods to energy insecurity in Harare, Zimbabwe. Households across all socio-economic backgrounds performed informal businesses to supplement household income and were heavily depended on the irregular electricity supply. Women from poor households managing informal businesses were disproportionately affected by the unstable electricity supply, as they could not afford alternative energy sources to continue business operations during power cuts. This accentuated their low adaptive capacity and vulnerability to climate change induced stresses. This paper brings to light the importance of improving the resilience and adaptive capacity of urban livelihoods to climate change related challenges like energy insecurity, whilst exploring climate-resilient energy options to sufficiently mitigate against the impacts of climate change on energy security.

Keywords: energy security, urban livelihoods, climate change, hydropower, informal sector

\section{INTRODUCTION}

Climate change has the potential to negatively impact on water dependent power generating technologies like hydropower. This is evident in Africa as droughts have historically disrupted hydropower generation, reducing plants to half of their capacity, leading to power rationing (Chenje and Johnson, 1996; Mukheibir, 2007; Zambezi River Authority, 2016, 2019). This exposes Africa's dependency on hydropower and highlights the continent's vulnerability to energy insecurity. It puts regional economic development at risk as energy drives commerce, predominantly in cities where energy demand continues to grow [International Energy Agency (IEA), 2020]. Furthermore, energy supports the success of urban sources of livelihood like the informal sector, primarily practised by the urban poor. Their adaptive capacity is low; hence they are more vulnerable to energy insecurity. 
Whilst the overall impacts of climate change on global hydropower potential appear to be slightly positive or impact minimally, IPCC (2011) and Hamududu and Killingtveit (2012), the high climate variability of Southern Africa poses a concern for hydropower potential in the region.

Africa's energy configuration with regards to access and demand is unique. Whilst energy demand on the continent is growing faster than the global average [International Hydropower Association (IHA), 2020], it accounts for a low share of the world's energy demand and high share of the global population without access to modern energy services [International Energy Agency (IEA), 2019]. The continent accounts for $17 \%$ of the world's population and only takes up $4 \%$ of the world's energy demand [International Energy Agency (IEA), 2019; International Hydropower Association (IHA), 2020]. Despite its low energy demand globally, rapid economic growth in sub-Saharan Africa since 2000 has seen an increase in energy use by $45 \%$ [International Energy Agency (IEA), 2014]. Its access to electricity grew to about $45 \%$ in 2018, according to the International Hydropower Association (IHA), (2020) and the International Energy Agency (IEA), (2020). Undeniably, increases in energy supply is necessary for the continent's prosperity. Climate change's potential impact on energy generation adds on to the complexities of energy security on the continent.

Remarkably hydropower makes a significant contribution to Southern Africa's energy mix. Within the region (except South Africa), more than $60 \%$ of the countries are dependent on hydropower mainly generated in the Zambezi River Basin (ZRB), with dependency even higher for some nations [International Energy Agency (IEA), 2010; Beilfuss, 2012]. In addition, hydropower contributes to about $40 \%$ of the regional power capacity with over $40,000 \mathrm{MW}$ in generation potential (SpaldingFecher et al., 2017). The International Energy Agency (IEA), (2020) indicates that on average, $17 \%$ of electricity generated on the African continent is from hydropower and projected to increase to about $23 \%$ by 2040 . Although hydropower is capital intensive and has a longer return on investment, it is clean, has low operational costs, it is reliable, can meet peak demand, and not subject to international price fluctuations compared to fossil fuels (IPCC, 2011; Mukheibir, 2013; Cole et al., 2014; IRENA, 2020). This has made it a favourable option for electricity generation and future expansion projects for many countries. However, obsolete and aged hydropower plants result in it not generating at capacity as $60 \%$ of hydropower plants on the continent are aged 20 years. Their age, together with the effects of climate change, have affected average annual growth of hydropower capacity in Africa, dropping it to $2.4 \%$ per year [International Hydropower Association (IHA), 2020]. This situation takes away from the potential increase in energy supply, affecting economic growth of the continent, with climate change exacerbating the situation.

Zimbabwe is a relevant example to exemplify these broader issues of climate change and energy insecurity. The country's electricity demand is just over 2000 megawatts (MW), Afshar (2018), with an installed capacity of about 2000 MW [Brown et al., 2012; Kaseke, 2013; Afshar, 2018; Zimbabwe Power
Company (ZPC), 2018]. However, it has failed to meet demand since the late 1990s. Makonese (2016) points out that these shortages could have been associated with increased urbanisation that shot demand together with insufficient investment in energy expansion. Zimbabwe's installed capacity mainly comprises of Kariba Hydropower Station at $1050 \mathrm{MW}$ and Hwange Thermal Power Station (coal) at $920 \mathrm{MW}$ [Brown et al., 2012; Kaseke, 2013; Afshar, 2018; Zimbabwe Power Company (ZPC), 2018]. Due to aged equipment, fuel shortages for diesel generators, and periodic low lake levels at Kariba, the country generates well below the installed capacity. Subsequently, it fails to meet the country's electricity demand. Massive power cuts lasting up to $16 \mathrm{~h}$ were experienced in Zimbabwe since the late $2000 \mathrm{~s}$ (Makonese et al., 2011). These could be associated with the economic challenges the country was facing. Evidently so, McGregor and Chatiza (2020) report economic decline by the end of the 1990s and the period between 1998 and 2008 "Zimbabwe's Crisis Decade" both politically and economically. Hence Zimbabwe's energy obstacles emanate from a multitude of reasons largely associated with economic decline. Moreover, these are compellingly related to available installed capacity, which continues to diminish due to extreme weather events like droughts.

The dependency on climate sensitive energy generating technologies is evident in Zimbabwe. Kariba Power Station contributes about $50 \%$ of installed capacity of electricity in Zimbabwe, and is the most reliable [Zimbabwe Power Company (ZPC), 2018]. Hwange Thermal Power Station generates between 400 and $500 \mathrm{MW}$, substantially lower than installed capacity (Afshar, 2018). The contribution from the rest of the thermal power stations in Harare, Munyati and Bulawayo is insignificant or non- existent most of the time (Brown et al., 2012; Kaseke, 2013; Afshar, 2018). This suggests hydropower to be the main source of electricity for Zimbabwe. However, historic droughts have reduced the Zambezi River's inflows into Lake Kariba, resulting in the reduced power generating capacity of Kariba Hydropower Station. Regional droughts in 1992/93 droughts and more recently in 2015/2016 reduced Kariba Dam's generating capacity by 8 and 11\%, respectively (Chenje and Johnson, 1996; NASA, 2016; Zambezi River Authority, 2016). In December 2019, NASA Earth Observatory images of Lake Kariba showed how much the reservoir had receded compared to the same period in 2018 (NASA, 2019). The Zambezi River Authority (ZRA) reported low dam levels at $8.50 \%$ of water usable for power generation (Zambezi River Authority, 2019) followed by massive power cuts of up to $18 \mathrm{~h}$ a day in Zimbabwe, threatening shut down of the dam if water levels continued to decline (Bloomberg News, 2019). These scenarios indicate the sensitivity of hydropower to climate variability and extreme weather events in Zimbabwe, together with the increased frequency of occurrence of these events. In addition, these repeated disruptions in electricity by climatic events threaten Zimbabwe's energy security and are largely felt in cities.

Establishing energy security in cities is of paramount importance. Largely so because they are energy intensive and consume about two thirds of global final energy use (REN21, 2020). However, there is limited research on how climate change 
might potentially impact energy availability in cities, where demand keeps increasing. It is rather focused on increase in energy demand in cities due to rapid urbanisation, especially in less developing countries (Madlener and Sunak, 2011). In addition, there has been less interest on climate change impacts on sources of livelihoods of the urban poor. Instead, many local governments have been more concentrated on poverty reduction than climate change adaptation as it was viewed as a means of reducing the vulnerability of the urban poor (Ka Lee, 2008). Most research on the vulnerability of the urban poor to the impacts of climate change focus on the direct impacts of extreme weather events on urban populations, or vulnerabilities due to lack of resilient infrastructure or services to the poor in urban areas (Carmin et al., 2012). In Zimbabwe, research on climate change impacts on livelihoods in limited and more centred on climate change impacts on rural livelihoods. This is possibly due to the agrarian based livelihoods in rural areas. Furthermore, climate change-energy research focuses on mitigation efforts rather than impacts (Haines et al., 2007; van Vliet et al., 2016). Moreover, studies that look at the climate change-water-energy nexus and urban livelihoods are scarce.

Energy plays a noteworthy role in alleviating poverty in urban areas. Brew-Hammond (2010) is of the opinion that to improve income generation in African communities, emphasis should be placed on productive uses of energy for income generation. His view implies that sectors like the informal sector could improve livelihoods of the urban poor if the energy required in these sectors is secured. This sector has grown over the years and its presence and role in providing income for urban populations acknowledged. The informal sector was well established by the 1960s, with Hart (1973) introducing the term "informal sector," referring to Ghana's towns (Potts, 2008). Nonetheless, it was internationally recognised in 1998 by the ILO in Kenya [International Labour Organization (ILO), 2003]. The International Labour Organization (ILO), (2003) defines the informal sector as all employment arrangements that do not provide individuals with legal or social protection through their work, thereby leaving them more exposed to economic risk than others, whether the economic units they work for or operate in are formal enterprises, informal enterprises, or households. In Zimbabwe, Informal Sector Operations (ISOs) include all enterprises not registered under the Companies Act or the Cooperatives' Act, together with those not assessed for taxation by central government (Paradza, 1999). The National Micro, Small, and Medium Enterprises Policy Framework of Zimbabwe acknowledges the informal sector and states that it is found in all sectors of the economy, predominantly lacks accountability, operates outside of the law and is not registered or licenced. The policy intends to formalise the informal sector which is largely constituted of micro enterprises (Government of Zimbabwe, 2015).

Literature suggests that the informal sector in poor countries grew as rapid urbanisation did not tie in with significant growth in the formal sector, hence, jobs in the formal sector were scarce (Potts, 2008). Numerous studies have linked growth of the informal sector in less developed countries with the period after Structural Adjustment Programmes (SAPs) by the
IMF and World Bank had been implemented, from about the 1980s. This was the case in Zimbabwe. The sector had an insignificant role to play before this period, as the formal sector was booming immensely in urban areas (Cobbe, 2002; Chirisa, 2009; Sparks and Barnett, 2010). Government spending was greatly cut, job losses rose and economic hardships grew, forcing urban populations to develop diversified livelihood strategies as the economy shifted (Chirisa, 2009; Njaya, 2015). The above trend insinuates that as economies of countries struggle, the informal sector grows as it tends to swell during periods of adjustment when employees are laid off. This is supported in literature (Calvès and Schoumaker, 2004; Yuki, 2007; Sparks and Barnett, 2010; Benjamin and Mbaye, 2014; Njaya, 2015) and explains the continued growth of the informal sector in Zimbabwe which often goes through waves of economic challenges. Understandably, a study by the IMF found Zimbabwe to have one of the largest informal economies as a percentage of its economy in the world (Medina and Schneider, 2018). This highlights its contribution to the livelihoods of the population, creating employment and income. Energy consumption in informal sector enterprises is characterised by low to medium energy intensity compared to other high intensity formal sectors like the heavy industries (Karekezi and Majoro, 2002). It is also thought to be labour intensive rather than capital intensive as the scale of production is small, suggesting low energy use (Ihrig and Moe, 2004). However, this does not diminish the importance of availability of energy to this sector. A few studies have highlighted how the livelihoods of people in the informal sector heavily depend on availability of electricity for them to perform their trades and earn income (Karekezi and Majoro, 2002; Chen et al., 2016). Energy availability drives and grows this sector as a lot of the trades in the informal sector are energy dependent.

Activities performed in the informal sector are done either as coping strategies of individuals, or families in environments where earning opportunities are scarce. Zimbabwe began experiencing economic challenges from the 1990s when the economic structural adjustment program was implemented, with the years 1998 to 2008 identified as the crisis decade by McGregor and Chatiza (2020) both economically and politically. The dollarization of the economy from 2009 brought some sensible stability and economic recovery. Regardless, poverty is still experienced by the country's citizens. The Total Consumption Poverty Line (TCPL) for an average of five persons per household stood at $\$ 563.00$ in June 2018, whilst that for one person stood at $\$ 113.00$ (Zimstat, 2018). It represents the total income needed for an individual (with all their income added together) as a minimum for them not to be deemed poor (Zimstat, 2018). Thus the informal sector provides a means of alleviating poverty. It is a source of income for retrenched professionals, skilled artisans, graduates entering the job market and uneducated and unskilled persons looking to earn a living (Karekezi and Majoro, 2002; Haan and Maclean, 2006; Potts, 2008; Chirisa, 2009, 2013; Schneider et al., 2010; Benjamin and Mbaye, 2014; Njaya, 2015). About $93 \%$ of new jobs created in sub-Saharan Africa during the 1990s were in the informal sector Chen (2001, 2016), with about $80 \%$ of total employment in sub-Saharan Africa in the informal economy (Charmes, 2012). The sector continues to 
grow in Zimbabwe and contributes to household food security due to the commoditization of urban areas.

Women dominate the informal sector as it provides an opportunity for them to earn an income and perform their domestic roles determined by restrictive cultural barriers and lack of formal training and skills (Eapen, 2001; Chirisa, 2009; Fapohunda, 2012; Benjamin and Mbaye, 2014). The sector empowers women as they are normally self-employed or unpaid home-based workers (Chen, 2001; Charmes, 2012; Chirisa, 2013). Similarly in a study in Zimbabwe, the International Labour Organization (ILO), (2017) found $94.9 \%$ of women in the informal sector constituting own-account workers. It found women involved in various trades from cross border trading, vending, services, manufacturing, welding mining, and stone quarrying. Similar trades were observed by Chirisa (2013) and Chen and Sinha (2016). Despite the gendered landscape of some informal trades, the participation of women in some male dominated trades highlights the severity of unemployment or income sources of urban households in Zimbabwe. Whilst some literature suggesting that women in informal work are uneducated, the International Labour Organization (ILO), 2017 study found $67.7 \%$ of women in informal work in Zimbabwe had at least attained secondary education. Gindling and Newhouse (2014) add on by stating that own-account workers fall between educated and least educated. Incontrovertibly building adaptive capacity and resilience of the informal sector preserves its function as a source of livelihood for the urban population, and in particular women.

\section{MATERIALS AND METHODS}

\section{Sampling and Data Collection}

This paper is based on data which was collected between April and June 2018 in Harare, Zimbabwe. The purpose of the study was to establish the relation between changes in climatic conditions and energy insecurity and how they combine to influence sustainable urban informal livelihoods. A household survey, by use of open and closeended questionnaires was conducted over 3 months to collect qualitative and quantitative data from women in the informal sector (Supplementary Data Sheet 1). The target population was women in home-based informal work who are dependent on electricity to operate their businesses. Studies have shown that women dominate the informal sector as a source of employment. However, most women in the informal sector in Harare are involved in petty commodity trade and vending in multiple locations, which do not require the use of electricity, hence these women were excluded from the survey. Rather the focus was on women in home-based trades as these are usually unaccounted for in labour force surveys. The paper focused on the informal sector referred to by the International Labour Organization (ILO), (2003). Their activities covered tailoring and grinding (mealie-meal, peanut butter), food services (catering, baking, food processing, refrigeration, etc), to hairdressing, printing, and packaging. The questionnaire was developed using the nine steps to develop questionnaires by Churchill and Iacobucci (2002). The survey gave a broad extensive profile of women in the informal sector, including their demographics and socio-economic status. The questionnaire also provided information on how availability of electricity affects their trades and livelihoods. Moreover, information on the strategies employed by women in home-based informal work when electricity is unavailable was collected.

The study was located in Harare, the capital city of Zimbabwe. The central business district (CBD) is its core, with the industrial areas to the east and south (Gamanya et al., 2009). The low density residential areas on spacious plot sizes of about 1000 $\mathrm{m}^{2}$ or more, are mainly located in the north and northeast with some medium density residential areas measuring between 800 and $1000 \mathrm{~m}^{2}$ found in the southern part. Conversely, the high density areas on plot sizes of about $300 \mathrm{~m}^{2}$ are to the extreme east, south, southwest and west of the city (Gamanya et al., 2009; World Bank, 2014). Indeed, Zimbabwe's stringent and well-institutionalised urban planning bureaucracies, inherited form the Rhodesian era are lauded in literature (McGregor and Chatiza, 2020). The white colonial settlers divided the city along racial lines. They subdivided outlying private farms in the then Salisbury (now Harare) into large residential properties mainly in the north and eastern parts of the city (Zinyama, 1993). In contrast, low income native housing was developed in the south to accommodate the black working force. The settlers started with Harari (now Mbare) in 1907. Expansions continued as demand for cheap labour increased. Hence, Highfield, Mufakose, Rugare, Kambuzuma, Mabvuku, Marimba Park, Tafara, Glen View, Glen Norah, and Dzivarasekwa low income housing projects were developed. These were located in the south and west of the city within close proximity to the CBD and industrial areas for easy commute by the workforce and densely populated. Post-independence (after 1980), low income housing continued to grow in Kuwadzana, Warren Park, Hatcliffe, and Budiriro. At this point urban housing was now divided along socioeconomic lines (Zinyama, 1993; Brown, 2001; World Bank, 2014). This is still evident today. Low income high density residential areas experience poor and inadequate services and amenities when compared to high income, low density residential areas (Zinyama, 1993; Brown, 2001; World Bank, 2014).

Taking the above description of Harare's urban space into account, the participants of the study were drawn from nine different residential suburbs of Harare, differentiated by their population densities, income levels and geospatial locations. These were the high-density residential areas (HDRAs) of Warren Park, Kambuzuma, Kuwadzana; medium-density residential areas (MDRAs) of Tynwald, Parktown, Westlea, and low-density residential areas (LDRAs) of Borrowdale, Marlborough and Mount Pleasant illustrated in Figure 1. For the purposes of this study assumptions were made based on socioeconomic divisions of the city's residential areas that the HDRAs and MDRAs in the south and south west of Harare are where the low- and middle-income urban populations reside, and the LDRAs of the north and north east are where the high-income urban populations reside. Hence the study had three strata, allowing for a comparative study to be carried out on demographics, livelihood strategies and adaptive 


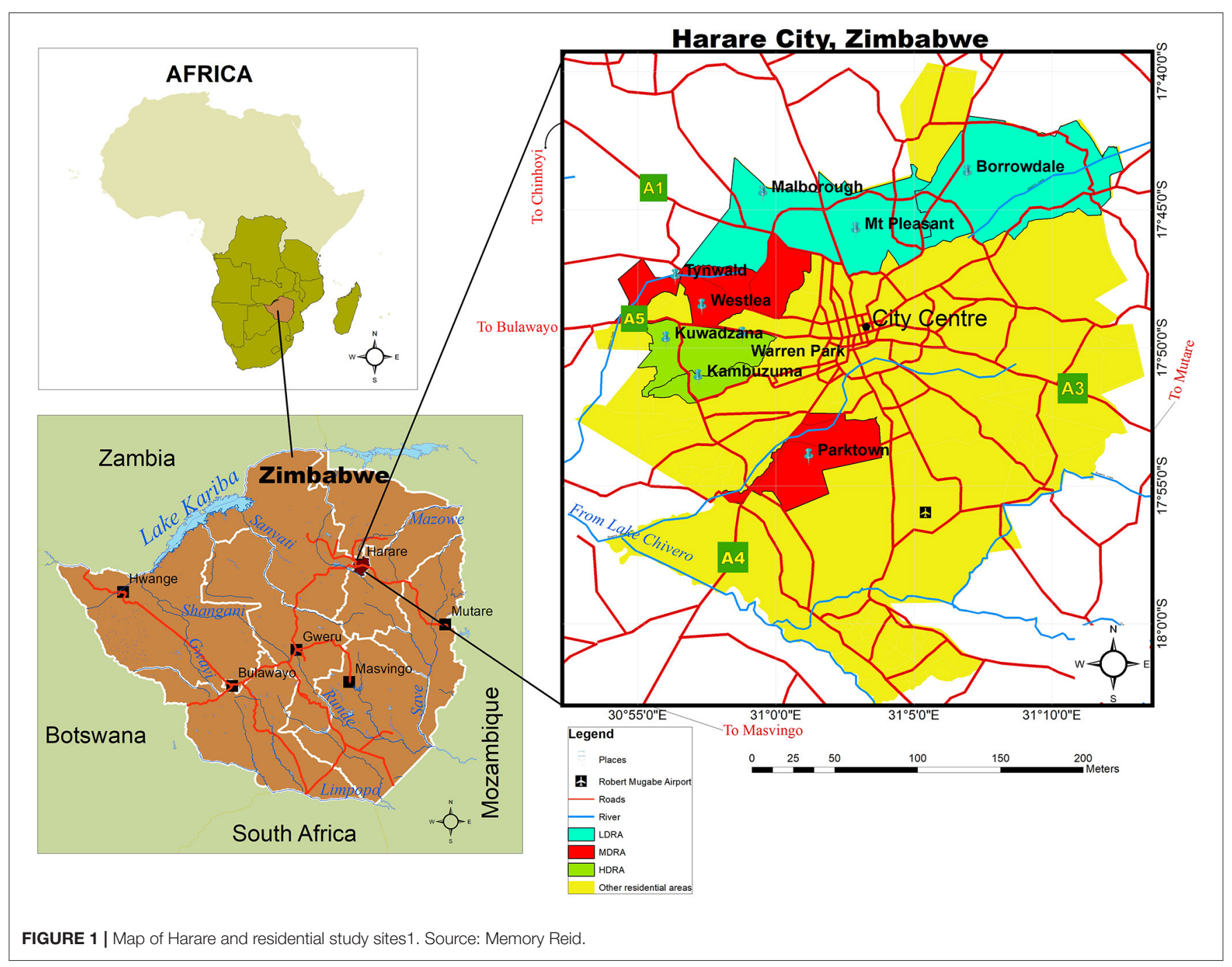

strategies employed by different urban populations in different residential areas.

The informal sector of Zimbabwe has 450, 816 women, with $16.7 \%$ belonging to the province of Harare (Labour Force Survey, 2014). However, there are no statistics on the women in homebased informal work, making it difficult to calculate a sample size to represent the women in home-based informal work in Harare. In addition to this, the household survey sampled respondents whose trade was based in their residential homes, making it difficult to locate them. Based on that, the study did not work with a sample size, but randomly selected the first participant in the study and used a combination of convenience sampling and the snowballing technique or referral method to get the next participant. Locating respondents from LDRAs was difficult compared to MDRAs and HDRAs as houses in LDRAs are sparsely distributed compared to MDRAs and HDRAs. The same applied to MDRAs compared to HDRAs. Based on this more participants were sampled from HDRAs, followed by MDRAs, with the least from LDRAs. We sampled 50\% of respondents from HDRAs, 33\% from MDRAs and 17\% from LDRAs. In total, the study had 150 respondents: 75, 50, and 25 from each stratum of HDRAs, MDRAs, and LDRAs, respectively.

\section{Analysis}

Quantitative methods were used to investigate how energy insecurity impacted on urban livelihoods. IBM SPSS Statistics software, together with Excel, was used to analyse the data collected from the household survey. Questionnaire responses were first edited, and cross checked for consistency and completion. Open ended responses from the questionnaires were classified into categories thereby converting qualitative data to quantitative data. The responses were quantified by looking for common themes in the responses and placing them into categories. Each response from the questionnaire was then coded and entered into an Excel spreadsheet. Coding involved assigning a numeric identifier to each response so that it can be run through a statistical software. These responses were run through IBM SPSS statistical software using the codes created. Anonymity of the respondents was maintained by assigning a number to each questionnaire instead of respondent's name. Data collected from 
the household survey was primarily presented using descriptive statistics in the form of means and frequencies presented in tables and charts. These helped summarise and allowed conclusions to be drawn about the study population. Contingency tables and Chi squared tests were used to analyse the associations between categorical variables. The chi-square test for independence, also called Pearson's chi-square test, was used to investigate whether two categorical variables had a relationship. $\mathrm{H}_{0}=$ no association/independence; $\mathrm{H}_{1}=$ association/dependence (Field, 2013). When there was a relationship, Phi and Cramer's V were used to test the strength of the association. Phi and Cramer's V vary between 0 and 1 without any negative value. Cramer's $V$ is an alternative to Phi in tables bigger than $2 \times 2$ tabulation. A value close to 0 signified weak or no association, but a strong relationship exists when the value is bigger than 0.25 (Akoglu, 2018).

\section{RESULTS}

\section{Socioeconomic Demographics}

Of the households surveyed, 52\% were female headed, with an average size of five people and $47 \%$ of the women were married. These women were educated, with most being employed in the informal sector as illustrated in Table 1. Only 116 of the 150 households gave responses on their household monthly income, earned in United States Dollars (USD). No households in LDRAs and MDRAs had household incomes at the lower end (\$101-300) as shown in Figure 2. Different households used various sources of income to sustain their livelihoods. The bulk of respondents' incomes were sourced from salaries and informal businesses. However, the LDRAs had more respondents that received remittances, while only $7 \%$ of HDRA respondents received pensions. A large number (76\%) of MDRAs had savings as part of their source of income, as represented in Figure 3. In the LDRAs, $72 \%$ of the respondents had access to credit, compared to 54 and $34.7 \%$ in the MDRAs and HDRAs, respectively. Put together, only $47.3 \%$ of the entire survey had access to credit. Property ownership in the different residential areas varied, with most residents in LDRAs having purchased the properties they lived in. Figure 4 shows that most respondents lived in homes that they had purchased. The LDRAs did not have any houses allocated to them through housing schemes that are usually provided for by government to low income groups. The ownership of other assets like cars was evident, with at least $44 \%$ of the households owning a vehicle. Only households in the LDRAs owned more than two cars.

The survey had most businesses (60\%), being own-account enterprises. There was significant evidence of an association, (chi- square $(2)=19.676, p<0.001$ ), between residential area and type of business (Table 2). Within HDRAs, 70\% of businesses were own- account enterprises, with LDRAs recording no contributing family workers. The study stems from looking at different home-based energy dependent businesses practised by women in urban areas. Figure 5 shows the most popular business was tailoring, closely followed by catering and hairdressing. Retailing, food processing, poultry, carpentry/welding, and recording studios were also visibly common.

\section{Income From Informal Businesses}

Of the 150 questionnaires administered, only 117 responded on monthly income from informal business. A close look at Table 3 shows most informal businesses generated a monthly income that ranged between $\$ 300-500$, closely followed by $\$ 101-\$ 300$. However, residential area influenced income generated by the businesses. There was significant evidence of a strong association (chi-square $(8)=58.242, p<0.00$; likelihood ratio $(8)=69.351$, $p<0.00$; Cramer's $\mathrm{V}=0.499$ ) between residential area and income from informal business. This was reflected by higher earnings in LDRAs and MDRAs when compared to the HDRAs. In LDRAs and MDRAs 70 and $60 \%$ of the businesses made between $\$ 301$ and $\$ 500$ monthly respectively, whereas in HDRAs, $35.1 \%$ of businesses earned $<\$ 100$ and $40.4 \%$ earned $\$ 101-300$. Furthermore, high earnings of $\$ 1,001-3,000$ were made by $20 \%$ of businesses in LDRAs, with the other areas making only 8 and $7 \%$. Therefore, the data suggests that most businesses in LDRAs and MDRAs earned incomes in the upper categories compared to those in HDRAs.

Operating businesses during power cuts, significantly contributed to monthly income. This was evident as there was a strong association, (chi-square $(8)=16.906 \mathrm{a}, p=0.031$; likelihood ratio $(8)=16.927, p=0.031$; Cramer's $\mathrm{V}=0.269$ ) between monthly income and business operation during power cuts as illustrated in Table 4. The data suggests that businesses that used manual equipment or substituted energy sources during power cuts earned more money than those that did nothing. However, the businesses that substituted for energy source made more money than those that used manual equipment. The businesses that did nothing mostly had income in the $<\$ 100, \$ 101-\$ 300$ and $\$ 301-\$ 500$ category $(14.8,44.4$, and $33.3 \%$ ), whereas $25 \%$ of those that used manual equipment fetched earnings in the upper categories of between $\$ 500-1,000$ per month. Furthermore, $11.5 \%$ of those that substituted energy sources, fetched earnings even higher, between $\$ 1,001-3,000$ respectively. This suggests that having alternative methods to continue working during power cuts was advantageous as it secured more income vs. not doing anything during power cuts. Earnings are further improved when the businesses managed to substitute energy source.

\section{Impacts, Adaptation, and Resilience to Energy Insecurity of Informal Business}

A majority of the enterprises use electricity to operate their machines and Figure 6 illustrates how electricity was used by the various informal businesses run by women in their households. Electricity was used mainly to operate machinery with heating, refrigeration and stitching being some of the other popular uses. Businesses had to find ways to stay open during load shedding. The majority, 63\%, substituted energy sources, while the rest used manual equipment or did nothing as they could not afford alternatives. There was significant evidence of a strong association, (chi-square $(4)=21.171, p=0.00$; likelihood ratio $(4)=23.784, p=0.00$; Cramer's $V=0.266$ ) as shown in Table 5. between business operation during load shedding and residential area. Within LDRAs and MDRAs, 76 and $80 \%$ of businesses 
TABLE 1 | Marital status, level of education and employment status of women in home-based informal businesses.

\begin{tabular}{llllll}
\hline Marital Status & Married & Single & Widowed & Divorced & N \\
\hline & $47.3 \%$ & $23.3 \%$ & $18.7 \%$ & $10.7 \%$ & \\
Education Level & Primary School & High School & Tertiary & & \\
& $3 \%$ & $56 \%$ & $41 \%$ & & \\
Employment Status & Full Time & Part Time & Informal & Unemployed & Retired/ Pensioner \\
& $21 \%$ & $13 \%$ & $60 \%$ & $3 \%$ & $3 \%$ \\
\end{tabular}

Source: Field Survey (2018).

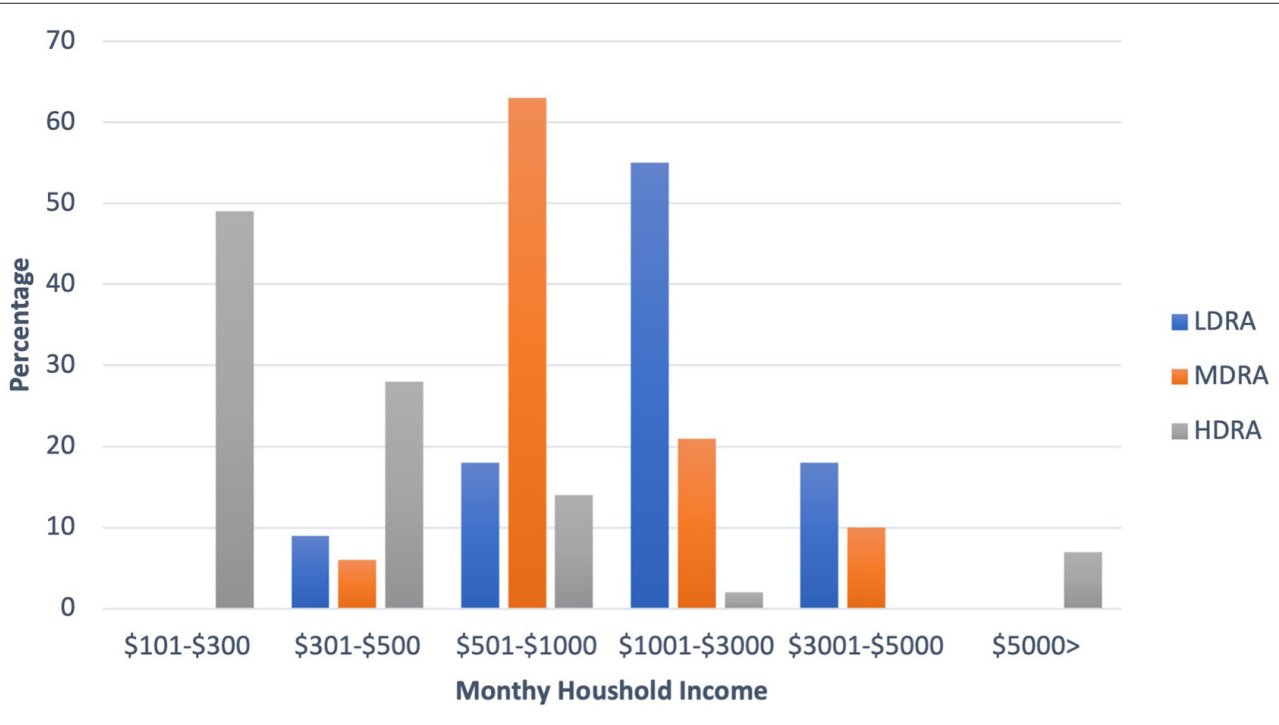

FIGURE 2 | Monthly household income in HDRAs, MDRAs and LDRAs (in USD). Source: Field survey (2018).

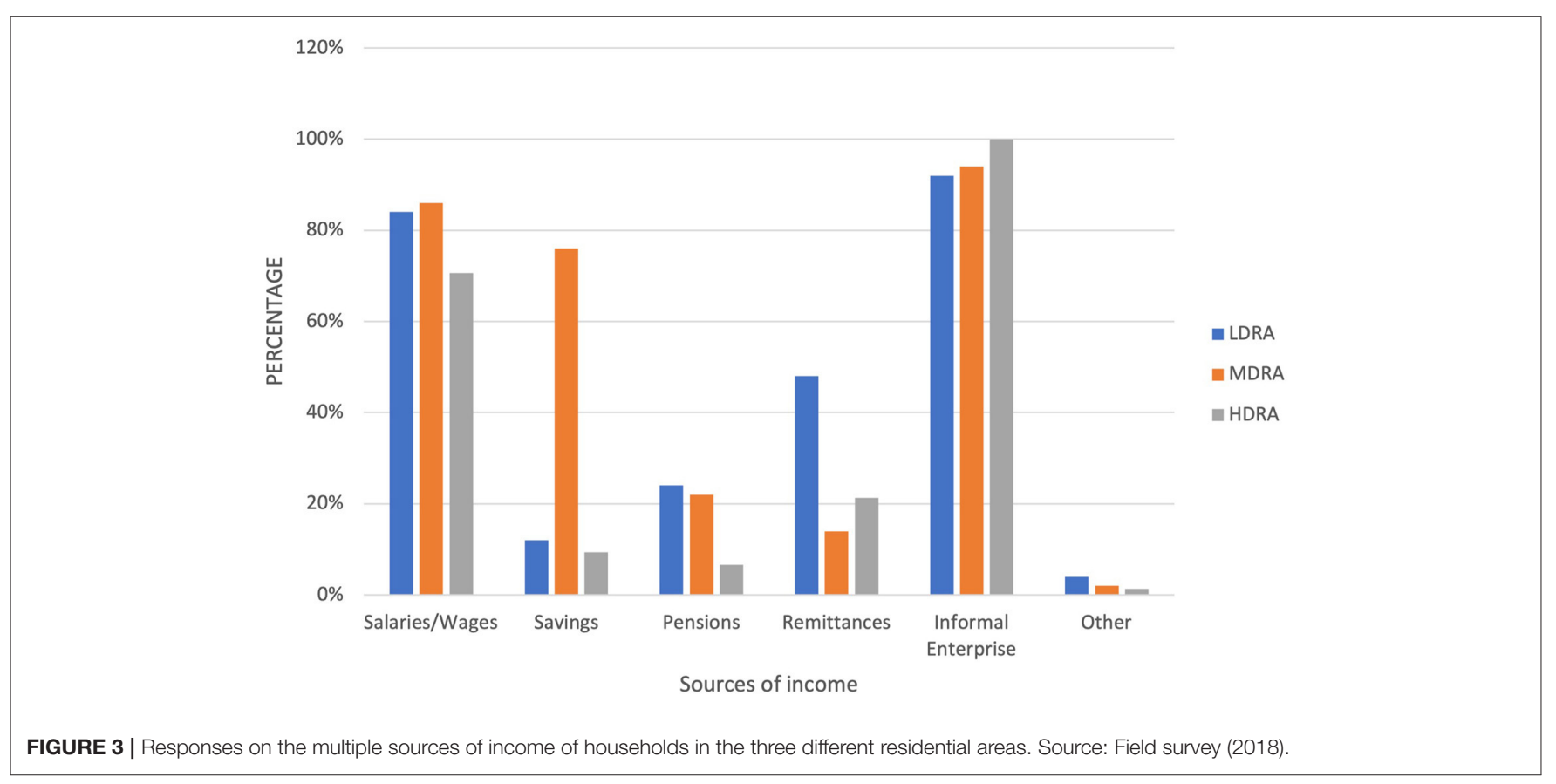




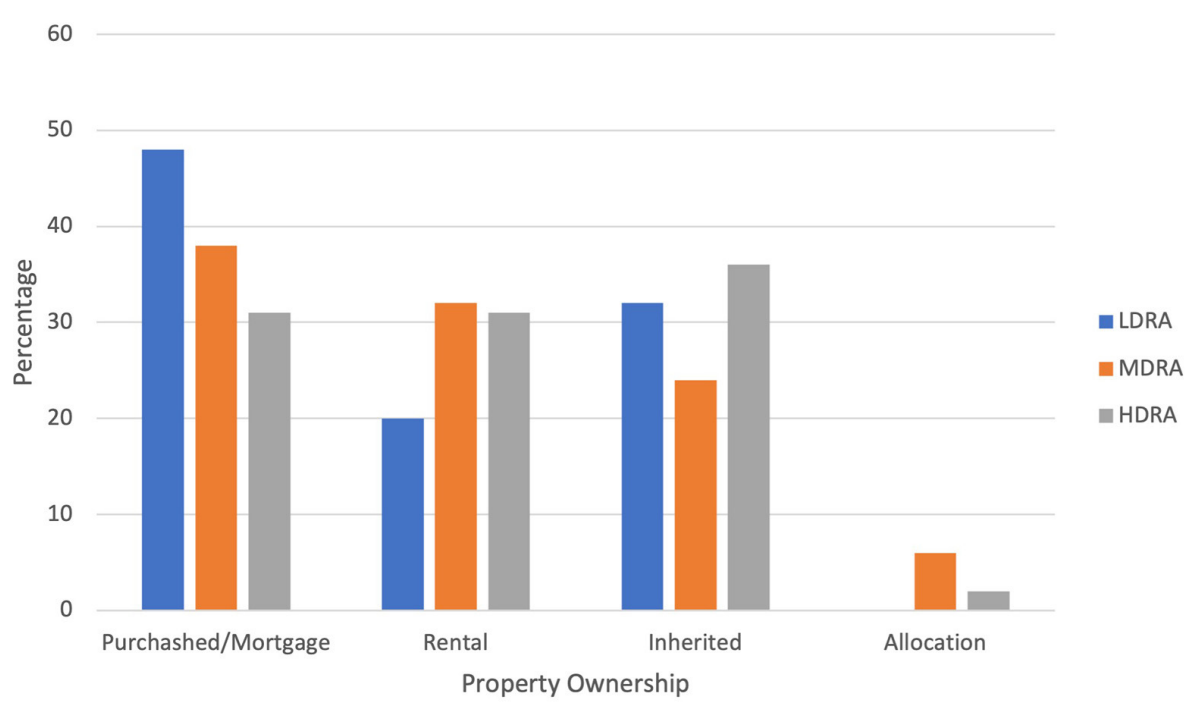

FIGURE 4 | Property ownership of households. Source: Field survey (2018).

TABLE 2 | Association between residential area and type of enterprise.

Type of enterprise

Total

Own-Account Enterprise Enterprise of Employers Contributing Family Workers

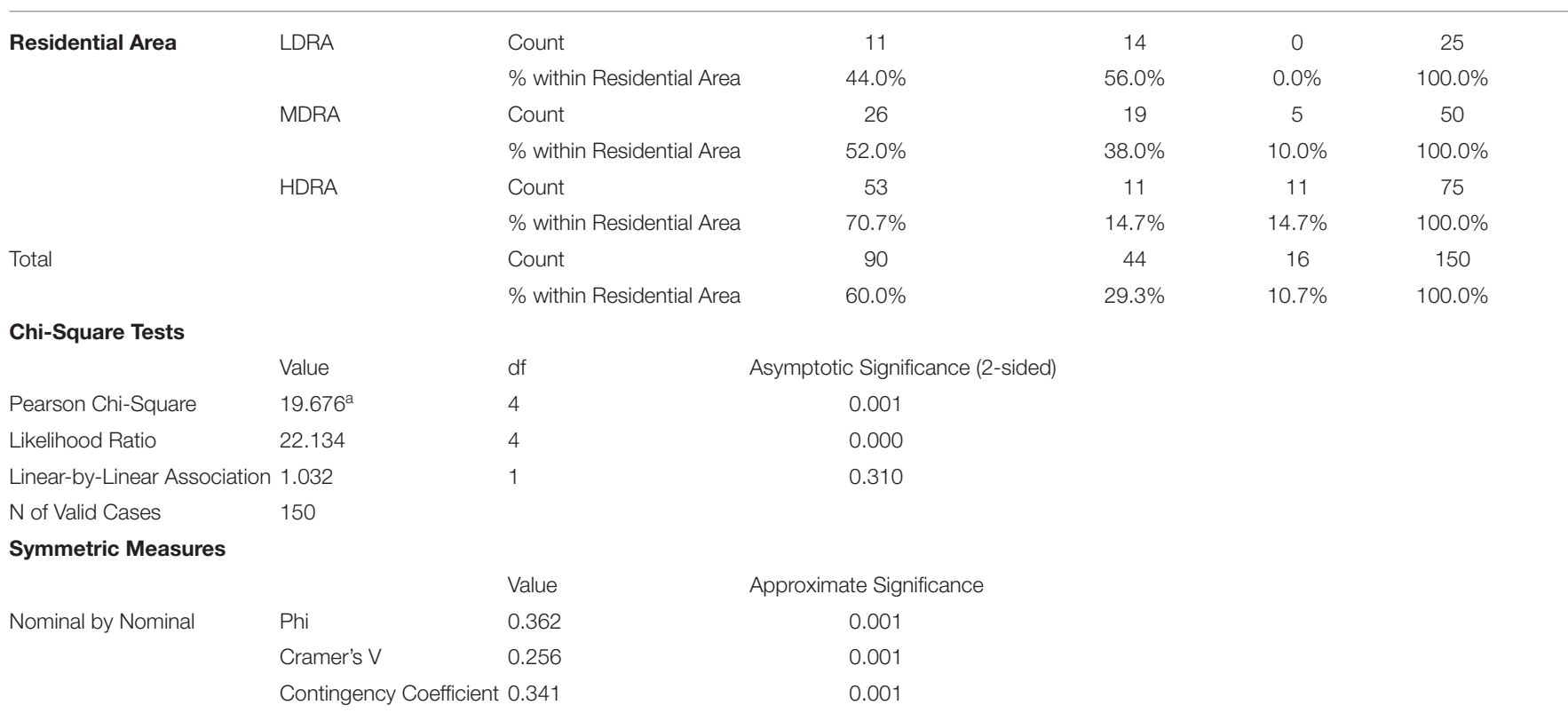

${ }^{a} 1$ cells (11.1\%) have expected count $<5$. The minimum expected count is 2.67. Source: Field Survey (2018).

used substitutes for electricity respectively. In comparison, only $48 \%$ of businesses in HDRAs could substitute for electricity, whilst a small minority either used manual equipment $(26.7 \%)$ or did nothing $(25.3 \%)$. Those that did nothing generated little income, as a strong association between income and operation during load shedding was indicated in Table 4. During load shedding, the businesses that substituted for electricity mainly opted for generators. However, the choice of substitute also had a significant association with the residential area, (chisquare $(10)=33.842, p=0.00$; likelihood ratio $(10)=36.199$, $p=0.00$; Cramer's $\mathrm{V}=0.336)$. The businesses operating in LDRAs and MDRAs opted for generators compared to those in 


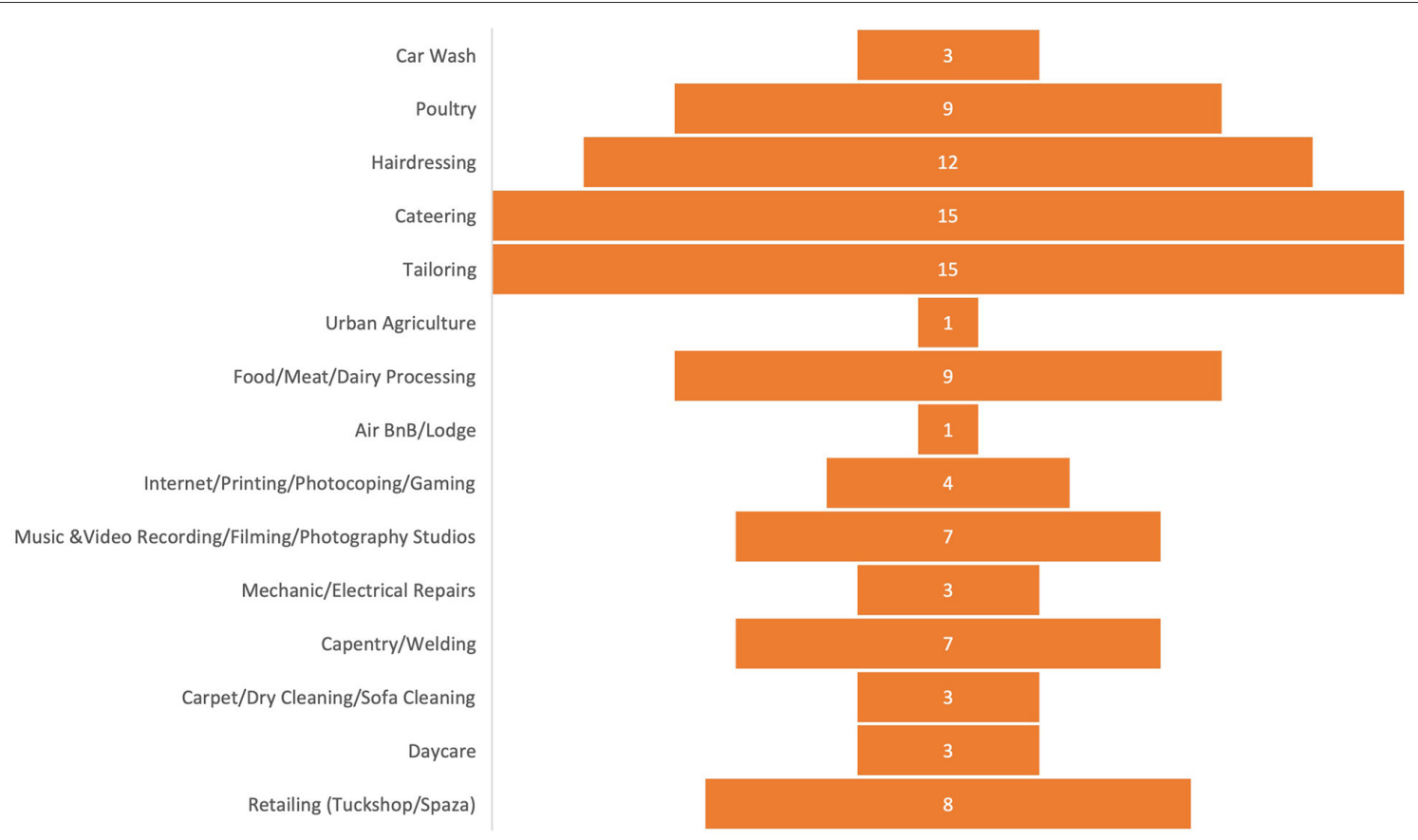

FIGURE 5 | Description of home-based electricity dependent informal businesses practised by women in percentages. Source: Field survey (2018).

TABLE 3 | Monthly income from informal businesses in the different residential areas.

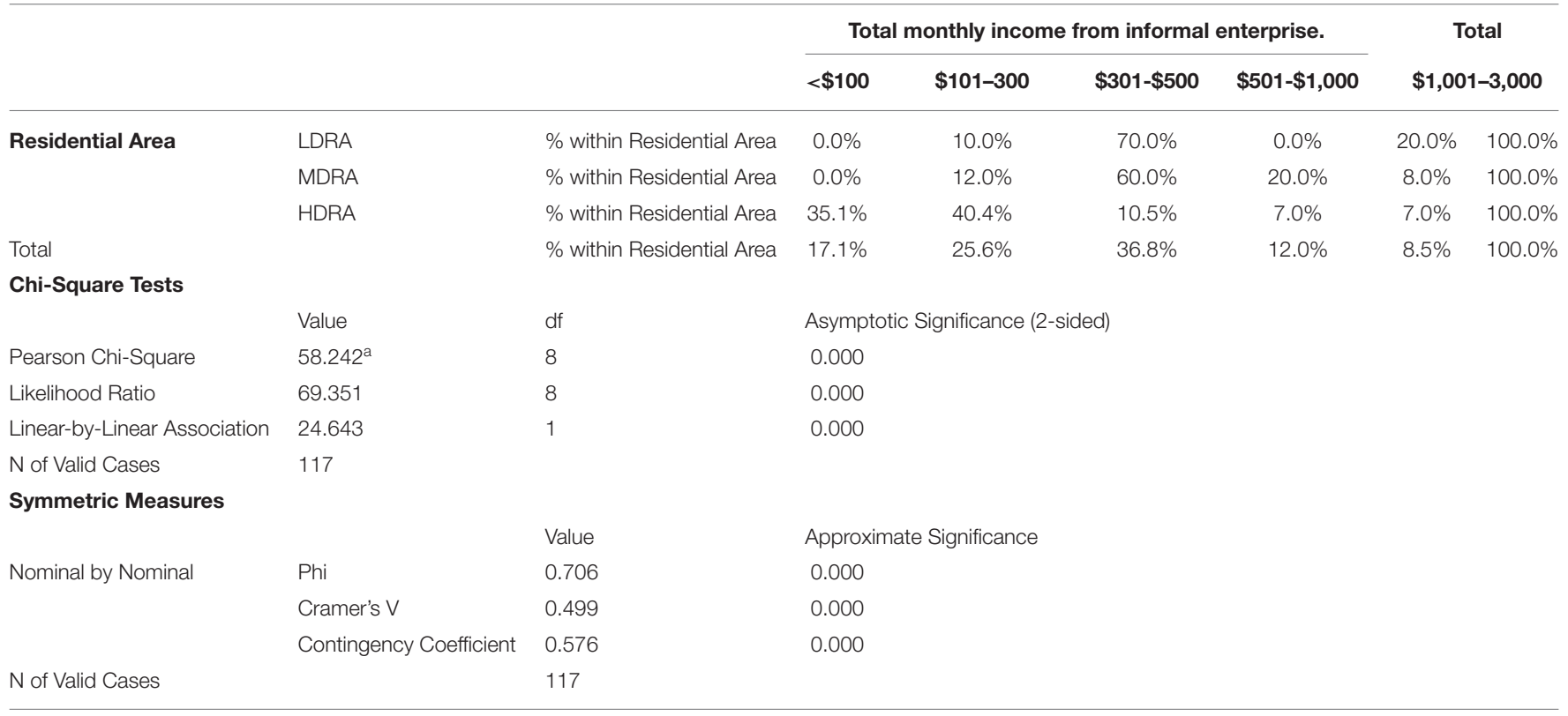

a cells (46.7\%) have expected count less than 5. The minimum expected count is.85. Source: Field Survey (2018).

HDRAs which opted for firewood/charcoal as shown in Figure 7, suggesting a cheaper alternative was chosen by households with a low-income status.

Load shedding had various effects on home-based informal businesses. A closer look at Table 6. shows that load shedding impacted on informal businesses in several ways. The large proportion (44\%) that substituted energy source found it to be costly and increased operational costs to make up for the additional cost incurred. Load shedding decreased production (78\%) and declined income earned $(75.2 \%)$ by home-based informal businesses. Businesses adapted differently to income losses in their business. The one item chosen by a larger 
TABLE 4 | Association of income from informal business and mode of operation during power cuts.

\begin{tabular}{|c|c|c|c|c|c|c|c|c|}
\hline $\begin{array}{l}\text { Business operation } \\
\text { during power cuts }\end{array}$ & $\begin{array}{l}\text { Manual } \\
\text { Equipment }\end{array}$ & $\begin{array}{l}\% \text { within Business } \\
\text { operation during } \\
\text { power cuts }\end{array}$ & \multicolumn{4}{|c|}{ Total monthly income from informal enterprise. } & \multicolumn{2}{|c|}{$\begin{array}{c}\text { Total } \\
\$ 1,001-3,000\end{array}$} \\
\hline & $\begin{array}{l}\text { Substitute } \\
\text { Energy Source }\end{array}$ & $\begin{array}{l}\% \text { within Business } \\
\text { operation during } \\
\text { power cuts }\end{array}$ & $14.1 \%$ & $21.8 \%$ & $39.7 \%$ & $12.8 \%$ & $11.5 \%$ & $100.0 \%$ \\
\hline & Nothing & $\begin{array}{l}\% \text { within Business } \\
\text { operation during } \\
\text { power cuts }\end{array}$ & $14.8 \%$ & $44.4 \%$ & $33.3 \%$ & $3.7 \%$ & $3.7 \%$ & $100.0 \%$ \\
\hline Total & & $\begin{array}{l}\% \text { within Business } \\
\text { operation during } \\
\text { power cuts }\end{array}$ & $17.1 \%$ & $25.6 \%$ & $36.8 \%$ & $12.0 \%$ & $8.5 \%$ & $100.0 \%$ \\
\hline $\begin{array}{l}\text { Linear-by-Linear } \\
\text { Association }\end{array}$ & 0.393 & 1 & \multicolumn{6}{|l|}{0.531} \\
\hline $\mathrm{N}$ of Valid Cases & 117 & & & & & & & \\
\hline \multicolumn{9}{|l|}{ Symmetric Measures } \\
\hline & & Value & \multicolumn{6}{|c|}{ Approximate Significance } \\
\hline \multirow[t]{3}{*}{ Nominal by Nominal } & Phi & 0.380 & \multicolumn{6}{|c|}{0.031} \\
\hline & Cramer's V & 0.269 & \multicolumn{6}{|l|}{0.031} \\
\hline & $\begin{array}{l}\text { Contingency } \\
\text { Coefficient }\end{array}$ & 0.355 & \multicolumn{6}{|l|}{0.031} \\
\hline $\mathrm{N}$ of Valid Cases & & 117 & & & & & & \\
\hline
\end{tabular}

a 8 cells (53.3\%) have expected count less than 5. The minimum expected count is 1.03. Source: Field Survey (2018).

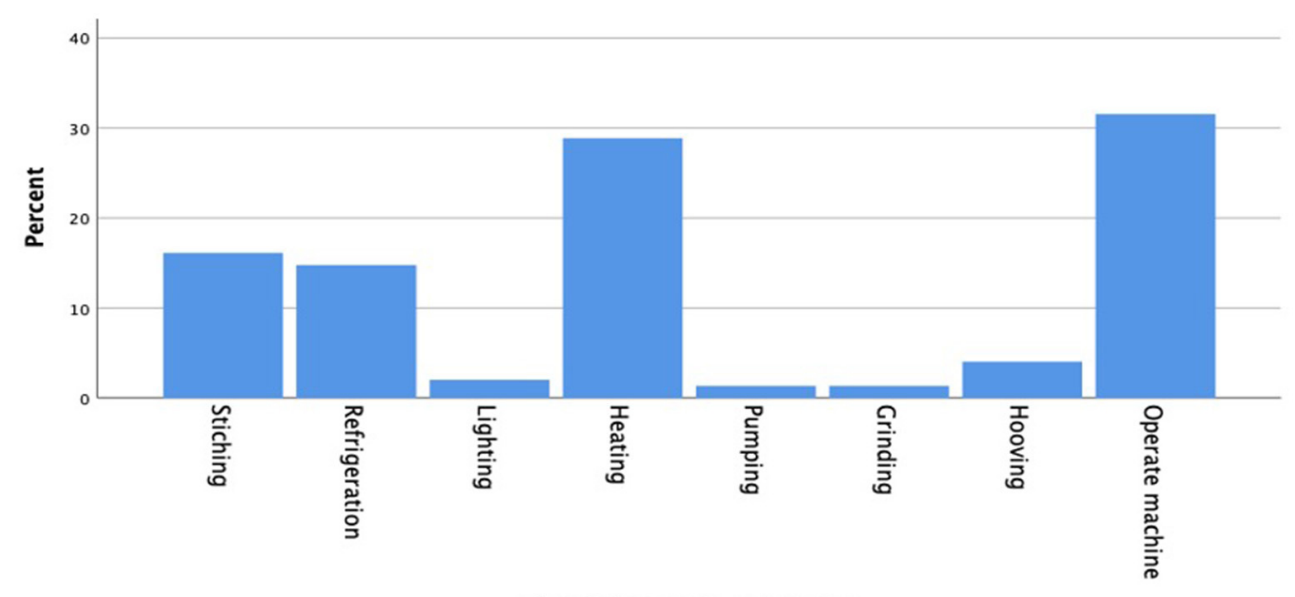

Electricity use in enterprise

FIGURE 6 | Different electricity uses in the enterprise. Source: Field survey (2018).

proportion of businesses to represent the major activity taken to adapt to the impact on income activity due to electricity cuts was to increase the cost of their products or services (Figure 8). Diversifying income generating projects in the household and working overtime when power returned were some of the other measures incorporated by households that depend on informal businesses as their sources of income. Electricity cuts disturbed customer relationships resulting in a lot of disgruntled 
TABLE 5 | Association between residential area and business operation during load shedding.

\begin{tabular}{|c|c|c|c|c|c|c|}
\hline & & & \multicolumn{3}{|c|}{ Business operation during load shedding/power outages } & Total \\
\hline \multirow[t]{2}{*}{ Residential Area } & LDRA & $\begin{array}{l}\% \text { within Residential } \\
\text { Area }\end{array}$ & $4.0 \%$ & $76.0 \%$ & $20.0 \%$ & $100.0 \%$ \\
\hline & HDRA & $\begin{array}{l}\% \text { within Residential } \\
\text { Area }\end{array}$ & $26.7 \%$ & $48.0 \%$ & $25.3 \%$ & $100.0 \%$ \\
\hline Total & & $\begin{array}{l}\% \text { within Residential } \\
\text { Area }\end{array}$ & $14.7 \%$ & $63.3 \%$ & $22.0 \%$ & $100.0 \%$ \\
\hline Pearson Chi-Square & $21.171^{\mathrm{a}}$ & 4 & \multicolumn{3}{|c|}{0.000} & \\
\hline Likelihood Ratio & 23.784 & 4 & \multicolumn{3}{|l|}{0.000} & \\
\hline $\begin{array}{l}\text { Linear-by-Linear } \\
\text { Association }\end{array}$ & 2.478 & 1 & \multicolumn{3}{|l|}{0.115} & \\
\hline $\mathrm{N}$ of Valid Cases & 150 & & & & & \\
\hline \multicolumn{7}{|l|}{ Symmetric Measures } \\
\hline & & Value & \multicolumn{3}{|c|}{ Approximate Significance } & \\
\hline \multirow[t]{3}{*}{ Nominal by Nominal } & Phi & 0.376 & \multicolumn{2}{|l|}{0.000} & & \\
\hline & Cramer's V & 0.266 & \multicolumn{2}{|l|}{0.000} & & \\
\hline & $\begin{array}{l}\text { Contingency } \\
\text { Coefficient }\end{array}$ & 0.352 & \multicolumn{2}{|l|}{0.000} & & \\
\hline
\end{tabular}

${ }^{a} 1$ cells (11.1\%) have expected count less than 5. The minimum expected count is 3.67. Source: Field Survey (2018).

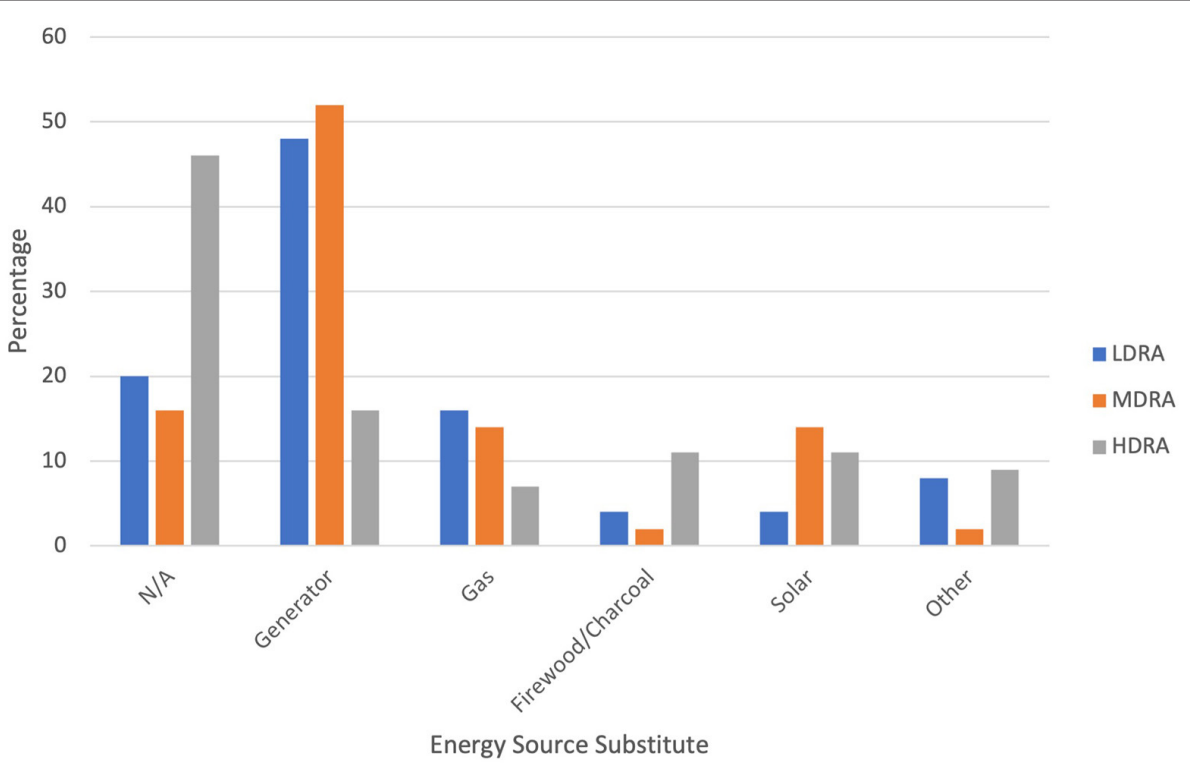

FIGURE 7 | Types of electricity substitutes in different residential areas. Source: Field survey (2018). 
customers. This was mainly due to the fact that businesses could not meet set targets or produced poor products when they substituted energy sources. In addition, many products were also spoiled or damaged, especially for clients who used electricity for refrigeration. Respondents from the household survey gave various reasons that they perceived to be behind the electricity cuts highlighted in Figure 9. A lot of blame was placed on the economic challenges the country has been facing. Additionally, ZESA's inability to sufficiently maintain its equipment was also blamed. The respondents were also aware of the country's debt to the South African power utility (ESKOM), that exports electricity to Zimbabwe. However not a single respondent associated power cuts to climate change and low lake levels at Kariba Dam.

\section{DISCUSSION}

\section{Socio-Economic Background and Income From Informal Businesses}

The survey results show that high literacy rates are evident as women in home-based informal work are educated, with the majority having attained a high school or tertiary education qualification. This possibly assists them effectively run their businesses. Similar findings were observed by the International Labour Organization (ILO), (2017) were women surveyed had at least attained secondary education. Granting the fact that studies by Chirisa (2013) found women in the informal sector to be uneducated, he surveyed women in informal trades that included vending and hawking of retail goods. Those trades possibly required fewer skills in contrast to the current study which involved businesses that required electricity for production or service. This would, in some instances, require training or education to some level. In addition, Gindling and Newhouse (2014) point out that education levels in the informal sector of own-account workers falls anywhere between highly educated and least educated, further explaining the differences in the findings of the two surveys. The informal sector creates employment largely for women and has also been collectively observed by other authors (Chen, 2001, 2016; Karekezi and Majoro, 2002; Haan and Maclean, 2006; Schneider et al., 2010; Charmes, 2012; Chirisa, 2013; Brown and McGranahan, 2016; Chen et al., 2016). This study draws attention to the flexibility of the informal sector as other participants of the survey still held full time jobs whilst operating their informal businesses. It became an extra source of income hence it allows for diversification of livelihood strategies.Similar sentiments shared by Chirisa (2009) and Njaya (2015). It highlights the role those multiple incomes play in supporting households, as cities like Harare are largely commoditised and expensive. Food security amongst other factors can only be realised with sufficient income generation in the household. Additionally, women usually venture into informal trade as a survivalist economic activity to support the household income. The resourceful of women was evident in this research as they worked hard to support their families.

A larger proportion of households in the survey earned a decent amount of between $\$ 501-1000$ per month as their total household income. Furthermore a higher proportion of the informal businesses made between \$301-500 per month indicating the contribution of informal home- based work in supporting household income. At the time of the survey, the Total Consumption Poverty Line (TCPL) for an average of five persons per household stood at $\$ 563.00$ in June 2018, which represents the total income needed for a household (with all their income added together) as a minimum for them not to be deemed poor (Zimstat, 2018). This income earned from informal businesses substantially contributes to food security of urban populations and allows for a more comfortable life, underlining the role the informal sector plays in poverty alleviation. However, the HDRAs had the lowest tier of total household and informal businesses earnings. This supports assumptions made about lowincome earnings of households in HDRAs. There are exceptions, where, high-income earners still chose to live in HDRAs where accommodation and rates are much cheaper. This is evident as household income exceeding $\$ 5,000$ was recorded there. These observations collectively indicate the informal sector's contributions to income and employment of urban populations. Its role in poverty reduction and food security of urban populations is indisputable. The LDRAs households continued to match assumptions made about their income status. They are the only ones that received remittances potentially showing the differences in family success in the various residential areas. They possibly have relatives that have travelled abroad, and work elsewhere, and hence have the capacity to send money back to family. The study revealed that their asset base was the strongest as most respondents had purchased their own homes, had access to credit and could afford the luxury of having two or more cars per household compared to the other residential areas.

The home has been identified as an essential resource for home-based informal work (Chen et al., 2016). Therefore, it is not surprising that women in the study ventured into home-based informal work because of ease of doing business at home. It is convenient as workspace can easily be created and electricity is readily available in most homes. The businesses that are easy to set up in the home include poultry and tailoring amongst others. Therefore, women do not venture into the informal sector solely because they are unskilled or because social and cultural barriers dictate their role in the home as homemakers as mentioned by Eapen (2001) and Fapohunda (2012). However, working from home is advantageous as they can combine their home-based informal work with their domestic roles to enable them to earn an income. The same observations were also identified by Carr and Chen (2002). Most businesses were own-account enterprises highlighting how the informal sector empowers women as it made it possible for most women to own their own businesses entirely. This characteristic thought to be true of most of the workforce in developing countries (Charmes, 2012; Chen et al., 2016; Stuart et al., 2018). However, in the current study, in LDRAs, women chose to employ people to help run their businesses than have family members working in the businesses they ran, whilst in MRDAs and HDRAs, the contribution of family workers was present. This could be because LDRAs families are usually affluent and wealthier and would therefore 
TABLE 6 | Perceptions on impact of load shedding.

\begin{tabular}{llll}
\hline & N & Yes & No \\
\hline Increased expense of substitute energy source & 150 & $44.0 \%$ & $35.3 \%$ \\
Increase in operational cost & 150 & $44.7 \%$ & $20.7 \%$ \\
Decline in production due toload shedding/power outages & 150 & $78.0 \%$ & $20.7 \%$ \\
Decline in income due to loadshedding/power outages & 150 & $75.2 \%$ & $22.0 \%$ \\
\hline
\end{tabular}

Source: Field Survey (2018).

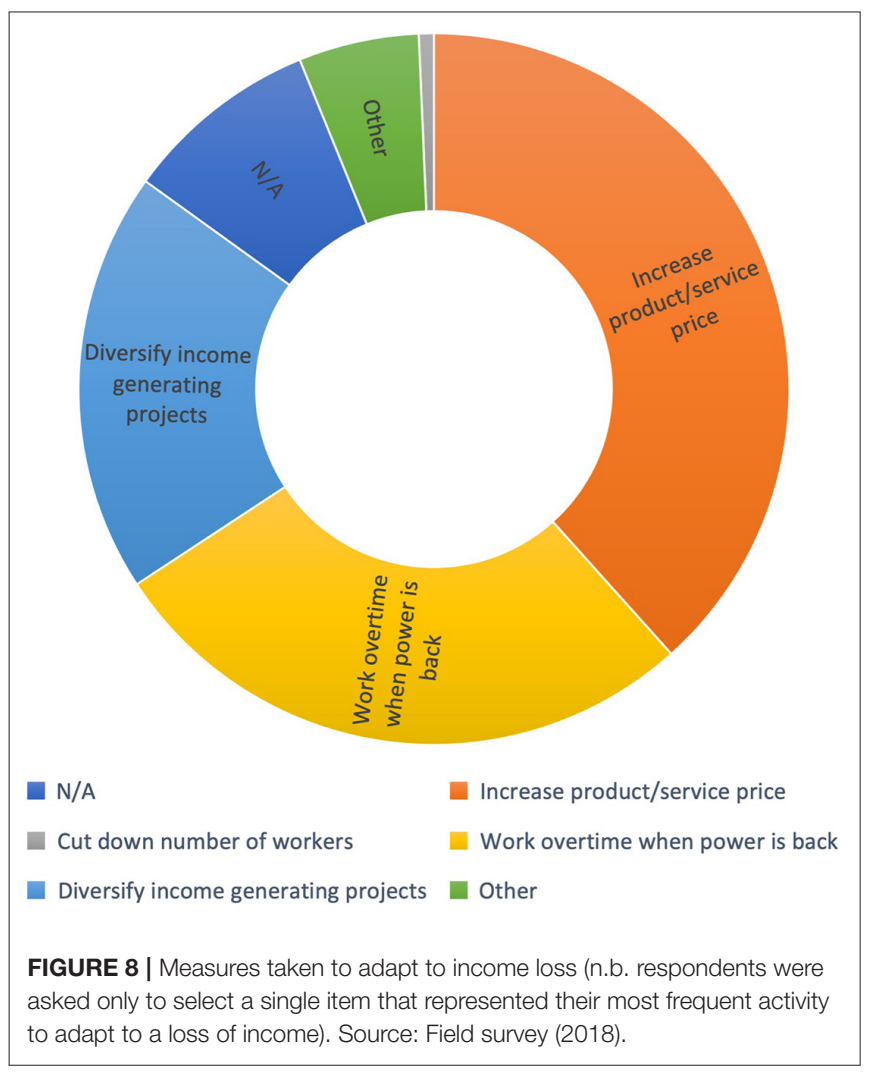

rather operate their businesses on their own or employ people to do so than involve their families for labour.

Women in home-based informal businesses performed a multitude of trades in Harare with tailoring, catering, and hairdressing being the most popular. They are generally easier to start, and common amongst women. Other trades like poultry, food processing, retailing, studios and, surprisingly, welding or carpentry were also common. In the typical male trades like welding and carpentry, it was usually men that did the work, while women were the administrators. In some instances, the women took over a family business after a spouse passed away and carried on with the previous employees or the sons managed the business. Other male dominated trades in the study where women oversaw the business but did not physically do the work included electrical repairs and car washing. The International Labour Organization (ILO), (2017) also observed women in male dominated informal work like welding and mining. However, the women also physically worked in those fields. The evidence presented in the study could be a reflection on the dire situation in the country that has forced women to venture in male dominated trades. It could also be an indication of modification of gender roles and increased women empowerment in Zimbabwe. It also indicates the survivalist nature of the informal sector where women will do whatever it takes to provide income for their households. These findings illustrate that the informal sector covers a wide range of labour markets and the conclusion that people in the informal sector practised whatever business was feasible to earn an income and sustain their livelihoods.

In addition to the ease of running from home, home-based informal businesses are operated from residential homes to reduce overhead expenses that come with operating in business centres. Transport and rental costs are eliminated, while saving time away from home (Chen and Sinha, 2016). Furthermore, location of business had an impact on income received from informal business as businesses in LDRAs and MDRAs made the most money, with less earned by businesses in HDRAs. However, in the study home-based informal businesses were practised in all residential areas regardless of income status. Households in Zimbabwe needed means to secure or supplement household income, regardless of their perceived economic status. This was also experience by Kazimbaya-Senkwe (2004), who found informal businesses in all residential areas, from the wealthy residential areas to the poor. It sheds light on the economic status of the country and how eroded income from formal jobs has become. It also highlights the survivalist nature of the informal sector and that it is indeed a livelihood strategy the aids households improve their income reducing poverty in urban areas.

\section{Impacts, Adaption, and Resilience of Urban Livelihoods to Energy Insecurity}

Electricity use in informal business drives the success of many home-based enterprises. In this study, electricity was mainly used for heating, machine operation and refrigeration, alluding to the various roles electricity plays in informal urban livelihoods. Hence access and availability of electricity is crucial for successful outcomes of home-based informal businesses. However, power cuts hinder the success of these electricity dependent businesses as energy insecurity was experienced by women in home-based informal urban work. Most households experienced electricity cuts in their homes every week and perceived to experience them more in the winter months of the year. Most national grids 


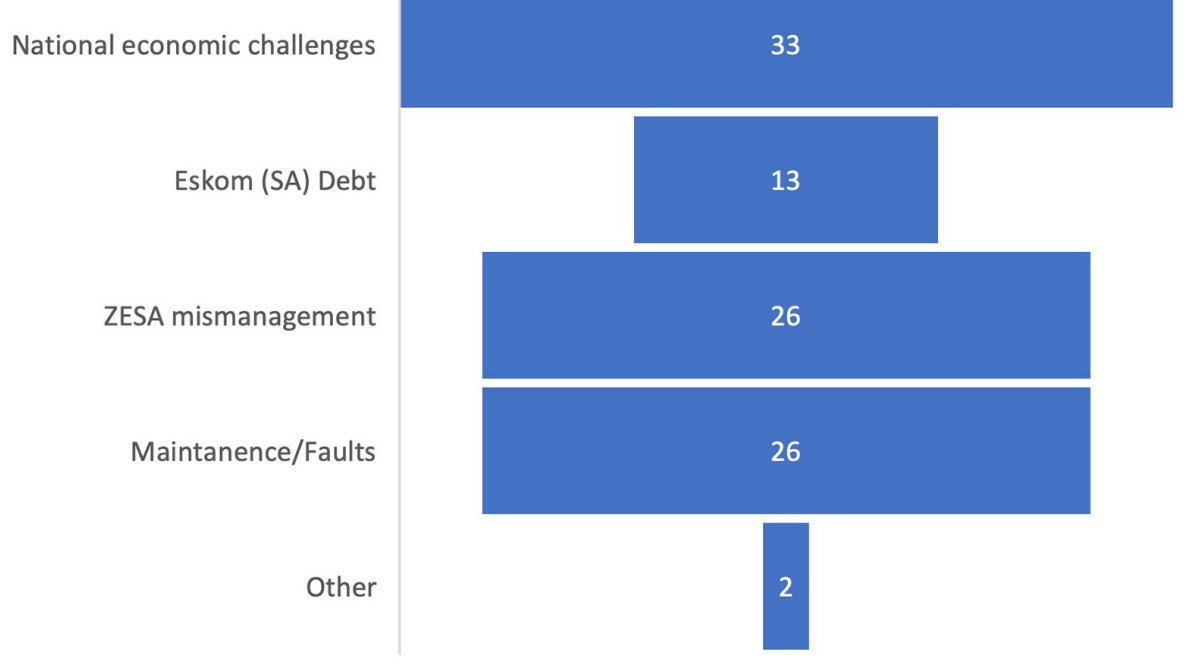

FIGURE 9 | Reasons behind load shedding in percentages. Source: Field survey (2018).

are strained in the winter months as electricity use for heating increases and likely the same experience of these businesses. The same likely occurs on long holidays. The year 2016 was revealed in the study to have the worst power cuts with 2013 to 2017 recording frequent power cuts. These years tie in with low lake levels at Kariba Dam in 2015/2016, which resulted in low generation capacity and subsequent power cuts as stated by the Zambezi River Authority (2016) and NASA (2016). The findings provide further support for the role a climate change-waterenergy nexus plays in energy security for Zimbabwe and how that impacts urban livelihoods. However, it was somewhat surprising that no respondent married the two but rather alluded to other factors like economic challenges and debt were behind the power cuts. This assertion draws attention to the economic challenges Zimbabwe has been facing. Citizens could only associate power outages to the economy. Even more so because most of them have been drawn into the informal sector to try an augment their earnings to adequately support their families.

The findings of this study indicated that a business' adaptive capacity to energy insecurity stresses strongly influenced income earned and success of the home-based informal business. Businesses that did not operate during power cuts earned less than those that substituted power sources or used manual equipment. These businesses continued to be productive even though power was cut as they found alternatives. However, how informal businesses adapted to power cuts had a bearing on income earned. This was reflected in the survey as most businesses that used manual equipment earned very little compared to those that substituted energy sources, as their scale of operation was substantially reduced, even though they continued to be productive during power cuts. Manual equipment was usually tedious to use, time consuming, output was low, and quality of product was not always up to standard. Similar views were expressed by dressmakers in Asia (Chen and Sinha, 2016), who mentioned the disadvantages of manual equipment as they took longer to produce product, product quality was lost leaving disgruntled customers and loss of business. These findings highlight how energy insecurity impacted on productivity and revealed businesses' low adaptive capacity. They belong to vulnerable groups that are usually located in low-income communities.

As power cuts frequently disturbed informal business operations, businesses were energy insecure and had to adapt by finding means to continue working and earn an income when power was cut. The prevalence of generator use to substitute for electricity in LDRAs and MDRAs compared to HDRAs continues to drive the narrative that residents in HDRAs have lower household incomes. This is further reflected by how different households in the various residential areas adapted differently. Residents in HDRAs did not substitute as extensively as other residential areas and used cheaper alternatives like firewood when they did substitute. This could be associated with limited resources, which left them with no option but to wait for electricity to return, exposing their low adaptive capacity. As observed earlier, doing nothing or using manual equipment impacted on the income from informal businesses and was the likely fate of businesses in HDRAs. Businesses in HDRAs has limited capacity to adapt to disturbances and looked for alternatives that are affordable but limit their advancement in the businesses they operate. Therefore, the evidence presented here indicates that energy insecurity is largely felt by the urban poor, as they are more vulnerable to environmental shocks due to their low asset base.

The ability to adapt to shocks continued be key to the survival of informal businesses when disturbances occurred. However, it brought with it new challenges. Alternative electricity 
sources were expensive, increasing operational costs of the businesses. Moreover, productive hours and income were lost when electricity was unavailable, which led to businesses adapting to protect their sources of livelihood. As such, most home-based informal businesses increased prices of product or service to recover losses due to power cuts. Where possible, diversification of income generating projects or working overtime when power was back were also other coping strategies employed by women in these informal businesses. The same pattern was also common in Asian cities as home-based informal workers worked overtime when power was back, to make up for lost productive hours during power cuts (Chen and Sinha, 2016). It sheds light on the resilience and fighting spirit of women in home-based informal businesses as they did whatever it took to earn income for their households. These findings also collectively highlight the challenges and struggles low-income groups face when disturbances occur. They resort to alternatives that are cheap, which limit their ability to effectively adapt to shocks and stresses, subsequently experiencing losses in income they desperately need. Hence, energy insecurity due to climate variability impacts the groups with the lowest adaptive capacity. These are usually the urban poor.

Power cuts continued to frustrate the efforts by women to earn income to offset the economic challenges experienced by most households. They disturbed businesses' relationship with clients as they failed to meet set targets or provide a service. Loss of customers in a flooded market are likely to have worsened the situation for most businesses at it takes time to build relationships with clients. Loss of product was equally dreadful as many products got damaged or spoilt, especially those requiring refrigeration during power cuts. These disturbances could possibly result in loss of business and livelihoods. This is likely true for businesses with limited resources to recover. The economic and electricity challenges facing the country are evident. It was not surprising that most respondents were aware that ZESA relied on exports and was indebted to the South African power utility, Eskom, as it is widely publicised. Furthermore, ZESA continues to struggle to maintain and service its equipment to the dismay of Harare's population that depends on electricity. Most citizens of Zimbabwe are familiar with the Kariba Hydropower Station as it is a massive structure and a tourist attraction, and many people vacation on Lake Kariba. The failure of any respondent to link the power cuts to climatic factors could suggest information on climate change and energy security matters are not widely made public or readily available in the public domain.

\section{CONCLUSION}

In this paper, it has been argued that the current dominance of hydropower in Zimbabwe's energy production structure and the increase in extreme weather events do not seem to offer a sustainable environment for socio-economic development. The country's dependence on an energy system which is vulnerable to changes in climatic conditions, together with the deteriorations in the energy infrastructure is increasingly threatening the livelihoods of many of the urban poor and not so poor households and communities. Moreover, whole livelihood options and incomes are dependent on the stable supply of electricity. There is therefore, an urgent need for both local and national authorities in Zimbabwe to identify avenues through which to, firstly; diversify the energy sources and secondly, build the adaptive capacity and resilience of the community to these energy insecurities they encounter.

It is important to note here that the informal sector in Zimbabwean cities like elsewhere in the developing south contributes significantly to household food security and income generations, particularly in female-headed households. Governments must integrate this important sector in urban planning and development plans. It is noted that the informal sector activities in many African cities including Zimbabwe are usually considered by the urban managers to be a nuisance to the overall urban landscape and are often marginalised in policies and development strategies. However, the empirical evidence presented in this paper suggests an urgent need for urban managers to rethink how these informal sector activities are supported through many initiatives among which include the supply of reliable and stable energy. There is an urgent need to establish pro-poor institutional and policy frameworks, which would act to enable and facilitate the engagement of the urban poor, particularly vulnerable women in more productive activities. It is through the establishment of working institutions and comprehensive policies, which are responsive to the realities and needs of the urban people that the informal sector will contribute in a meaningful way and significantly to economic growth and national development.

In view of the above assertions, we argue that future energy expansion projects should consider incorporating an energy mix that does not depend solely on a technology historically affected and predicted to continue to be affected by climate change. Climate smart technologies are of paramount importance in countries like Zimbabwe, where extreme weather conditions like drought are predicted to increase. Connected to this, is the need for more research on the impacts of climate change on urban livelihoods in developing cities particularly those in subSaharan Africa which are compounded by a number of factors such as high poverty levels, poor infrastructure, deteriorations in both national and local economies, weak institutional and policy frameworks and the lack of political will. With energy demand set to increase as urban populations continue to grow, threats on energy security due to climate variability and climate change need to be further investigated. This is crucial for Africa as it carries the fast urbanising cities in the world. In addition, studies in more cities together with larger sample sizes would allow for a comprehensive understanding of how a climate change-water-energy nexus impacts on urban livelihoods. The findings reported in the study can only be preliminary due to a small sample size. Further research needs to examine the role institutions play in supporting urban livelihoods in a changing climate. Local institutions like municipalities 
shape the impacts of external shocks like climate change and energy insecurity on communities. Therefore, they are key in shaping the resilience of urban livelihoods and protection of women's income generating opportunities. Collectively, the adaptive strategies in different cities and the role institutions play provide different approaches in adapting to a climate change-water-energy nexus, creating opportunities to develop frameworks and policies which may facilitate building the adaptive capacity and resilience of urban residents as well as those of whole cities.

\section{DATA AVAILABILITY STATEMENT}

The original contributions presented in the study are included in the article/Supplementary Material, further inquiries can be directed to the corresponding author.

\section{ETHICS STATEMENT}

The studies involving human participants were reviewed and approved by The University of the Witwatersrand Ethics Committee; Ethics Clearance Certificate Issued. The patients/participants provided their written informed consent to participate in this study.

\section{REFERENCES}

Afshar, S. (2018). Energy Sources and Policy in Zimbabwe. Available online at: http://large.stanford.edu/courses/2017/ph240/afshar1/ (accessed Septmber 09, 2020).

Akoglu, K. (2018). Blending online coursework and small learning communities to examine professional growth in teaching statistics: A phenomenological case study. Dissertation Abstracts International Section A: Humanities and Social Sciences.

Beilfuss, R. (2012). A Risky Climate for Southern African Hydro, International Rivers, Berkely. Available online at: http://climenews.com/letoltes/zambezi_ climate_report_final.pdf.

Benjamin, N., and Mbaye, A. A. (2014). Informality, growth, and development in Africa, WIDER Working Paper 2014/052, Helsinki: UNU-WIDER. Available online at: https://www.wider.unu.edu/sites/default/files/wp2014-052.pdf.

Bloomberg News (2019). Worlds biggest reservoir may stop producing power amid drought. Avalable online at: https://www.bloomberg.com/news/articles/201912-12/world-s-biggest-reservoir-may-stop-producing-power-amid-drought (accessed May 06, 2020).

Brew-Hammond, A. (2010). Energy access in Africa: Challenges ahead. Energy Policy 38, 2291-2301. doi: 10.1016/j.enpol.2009.12.016

Brown, A. (2001). Cities for the urban poor in Zimbabwe: Urban space as a resource for sustainable development. Developm. Pract. 11, 319-331. doi: 10.1080/09614520120056432

Brown, D., Chanakira, R. R, Chatiza, K., Dhliwayo, M., Dodman, D., Masiiwa, M., and Zvigadza, S. (2012). Climate change impacts, vulnerability and adaptation in Zimbabwe. London: International Institute for Environment and Development.

Brown, D. and McGranahan, G. (2016). The urban informal economy, local inclusion and achieving a global green transformation. Habitat Int. 53, 97-105. doi: 10.1016/j.habitatint.2015.11.002

Calvès, A. E., and Schoumaker, B. (2004). Deteriorating Economic Context and Changing Patterns of Youth Employment in Urban Burkina Faso: 1980-2000. World Development 32, 1341-1354. doi: 10.1016/j.worlddev.2004.03.002

Carmin, J., Anguelovski, I., and Roberts, D. (2012). Urban climate adaptation in the global south: planning in an emerging policy domain. J. Plann. Educ. Res. 32, 18-32. doi: 10.1177/0739456X11430951

\section{AUTHOR CONTRIBUTIONS}

All authors listed have made a substantial, direct and intellectual contribution to the work, and approved it for publication.

\section{FUNDING}

National Research Foundation (NRF). Re-centring AfroAsia Project (funded by the Andrew W Mellon Foundation). The University of the Witwatersrand Postgrad Merit Award.

\section{ACKNOWLEDGMENTS}

Gratitude is afforded MS from the Global Climate Institute (GCI) at the University of the Witwatersrand, my family, Dr. Anita Etale and the women in Harare, Zimbabwe that gave me their time during the household survey and allowed me into their homes.

\section{SUPPLEMENTARY MATERIAL}

The Supplementary Material for this article can be found online at: https://www.frontiersin.org/articles/10.3389/frsc.2021. 706476/full\#supplementary-material

Carr, M., and Chen, M. (2002). Globalization and the Informal Economy: How Global Trade and Investment Impact on the Working Poor, Working Paper on the Informal Economy Working No. 1 INTEGRATION (Geneva: International Labour Office).

Charmes, J. (2012). The informal economy worldwide: trends and characteristics. Margin J. Appl. Econ. Res. 6, 103-132. doi: 10.1177/0973801012006 00202

Chen, M., Roever, S., and Skinner, C. (2016). Editorial: Urban livelihoods: reframing theory and policy. Environ. Urbaniz. 95:2405. doi: 10.1177/0956247816662405

Chen, M. A. (2001). "Women and Informality: A Global Picture, the Global Movement”, SAIS Review, 21(1), pp. 71-82. doi: 10.1353/sais.2001. 0007

Chen, M. A. (2016). Women in the informal sector: a global picture, the global movement. SAIS Rev. 21, 71-82.

Chen, M. A., and Sinha, S. (2016). Home-based workers and cities. Environ. Urbaniz. 664:49865. doi: 10.1177/0956247816649865

Chenje, M., and Johnson, P. (1996). Water in Southern Africa. Harare, SADC Environment and Land Sector Coordination Unit.

Chirisa, I. (2009). The geography of informal sector operations (ISOs): a perspective of urban Zimbabwe. J. Geograph. Region. Plann. 2, 066-079. Available online at: http://www.academicjournals.org/JGRP

Chirisa, I. (2013). Characterising women in the informal sector and their struggles to Eke a Living lessons from Ruwa, Zimbabwe. J. Women's Entrepr. Educ. 12, 10-35. Available online at: https://EconPapers.repec.org/RePEc:ibg:jwejou: $\mathrm{y}: 2013$

Churchill, G. A., and Iacobucci, D. (2002). Marketing research: methodological foundations. 8th ed. Orlando, FL: Harcourt College Publishers.

Climate Change (2001). "Impacts, adaptation, and vulnerability," in Contribution of Working Group II to the Third Assessment Report of the Intergovernmental Panel on Climate Change. eds J. J. McCarthy, O. F. Canziani, N. A. Leary, D. J. Dokken and K. S. White (Cambridge: Cambridge University Press), 1032.

Cobbe, J. (2002). 'BOOK REVIEW: Mupedziswa, Rodreck, and Perpetua Gumbo. Women informal traders in harare and the struggle for survival in an environment of economic reforms. Research Report 117. Uppsala: Nordiska Afrikainstitutet, 2001.', Africa Today. doi: 10.2979/AFT.2002.49.3.131 
Cole, M. A., Elliott, R. J. R., and Strobl, E. (2014). Climate change, hydrodependency, and the african dam boom. World Develop. 60, 84-98. doi: 10.1016/j.worlddev.2014.03.016

Eapen, M. (2001). Women in informal sector in kerala: need for re-examination. Econ. Politic. Weekly. 36, 2216-2218. Available online at: https://www.epw. in/journal/2001/26/review-labour-review-issues-specials/women-informalsector-kerala.html

Fapohunda, T. M. (2012). Women and the informal sector in nigeria: implications for development. Br. J. Arts Soc. Sci. 4, 2046-9578. doi: 10.204b/journal.co.uk/BJASS.aspx

Field, A. (2013). Discovering statistics using IBM SPSS statistics, Statistics.

Gamanya, R., De Maeyer, P., and De Dapper, M. (2009). Objectoriented change detection for the city of harare, Zimbabwe. Exp. Syst. Appl. 36, 571-588. doi: 10.1016/j.eswa.2007.09.067

Gindling, T. H., and Newhouse, D. (2014). Self-employment in the developing world. World Develop. 2013:003. doi: 10.1016/j.worlddev.2013.03.003

Government of Zimbabwe (2015). Zimbabwe National Climate Change Response Strategy, Ministry of Environment, Water and Climate. Harare. Available online at: http://extwprlegs1.fao.org/docs/pdf/zim169511.pdf (accessed August 03, 2019).

Haan, H., and Maclean, R. (2006). "|Public Training Providers and the IME Sector," in Training for Work in the Informal MicroEnterprise Sector, 59-85.

Haines, A., Smith, K. R., Anderson, D., Epstein, P. R., McMichael, A. J., Roberts, I., et al. (2007). Policies for accelerating access to clean energy, improving health, advancing development, and mitigating climate change. Lancet 12, 1264-1281. doi: 10.1016/S0140-6736(07)61257-4

Hamududu, B., and Killingtveit, A. (2012). Assessing climate change impacts on global hydropower. Energies 5, 305-322. doi: 10.3390/en502 0305

Hart, K. (1973). Informal income opportunities and urban employment in Ghana opportunities and urban employment in Ghana. J. Mod. Afric. Stud. J. Mod. Afric. Stud. 11, 61-89. doi: 10.1017/S0022278X00008089

Ihrig, J., and Moe, K. S. (2004). 'Lurking in the shadows: the informal sector and government policy', J. Develop. Econ. 73, 541-557. doi: 10.1016/j.jdeveco.2003.04.004

International Energy Agency (IEA) (2014). Africa Energy Outlook. A focus on the energy prospects in sub-Saharan Africa, World Energy Outlook Special Report, International Energy Agency Publication. Available online at: https://www. icafrica.org/fileadmin/documents/Knowledge/Energy/AfricaEnergyOutlookIEA.pdf.

International Energy Agency (IEA) (2019). Africa Energy Outlook 2019 World Energy Outlook Special Report. New York, NY: EA Publications.

International Energy Agency (IEA) (2020). Climate Impacts on African Hydropower 2020, World Energy Outlook Special Report. New York, NY: EA Publications.

International Energy Agency (IEA) (2010). World energy outlook 2010. World Energy Outlook. Paris: IEA, 23, 326-328. Available online at: https://www.iea. $\mathrm{org} /$ reports/world-energy-outlook-2010

International Hydropower Association (IHA) (2020) "Hydropower status report 2020: Sector trends and insights", Hydropower Status Report. Available online at: https://www.hydropower.org/publications/2020-hydropower-status-report (accessed July 12, 2020).

International Labour Organization (ILO) (2003). "Guidelines concerning a statistical definition of informal employment, endorsed by the Seventeenth International Conference of Labour Statisticians (November-December 2003)," in Seventeenth International Conference of Labour Statisticians (Geneva, 24 November--3 December 2003), Report of the Conference; Doc. ICLS/17/2003/R; International Labour Office, Geneva, 2003

International Labour Organization (ILO) (2017). Situational analysis of Women in the informal economy in Zimbabwe. Available online at: https://www.ilo.org/ wcmsp5/groups/public/---africa/---ro-abidjan/---sro-harare/documents/ publication/wcms_619740.pdf (accessed September 20, 2020).

IPCC (2001). Intergovernmental Panel on Climate Change 2001. Singapore: IPCC.

IPCC (2011). Special Report on Renewable Energy Sources and Climate Change Mitigation. Cambridge: Cambridge University Press.

IRENA (2020). Renewable Power Generation Costs in 2019. Available online at: https://www.irena.org/publications/2020/Jun/Renewable-Power-Costs-in2019 (accessed September 24, 2019).
Ka Lee, J. W. (2008). Adaptation for the Urban Poor: Assessing the Tensions in the Climate Change and Urban Poverty Reduction Debates. UCL development planning unit. University College London. Available online at: https://www. ucl.ac.uk/bartlett/development/sites/bartlett/files/migrated-files/WP137_Internet_-_corrected_9.3.11_0.pdf

Karekezi, S., and Majoro, L. (2002). Improving modern energy services for Africa's urban poor. Energy Policy 30, 1015-1028. doi: 10.1016/S0301-4215(02)00055-1

Kaseke, N. (2013). Emergence of electricity crisis in zimbabwe, reform response and cost implications. J. Bus. Manage. Soc. Sci. Res. 2:201.

Kazimbaya-Senkwe, B. M. (2004). "Home based enterprises in a period of economic restructuring in Zambia," in Reconsidering Informality: Perspectives from Urban Africa, 25.

Labour Force Survey (2014). https://www.ilo.org/surveyLib/index.php/catalog/ 2779 (accessed October 08, 2017).

Madlener, R., and Sunak, Y. (2011). Impacts of urbanization on urban structures and energy demand: what can we learn for urban energy planning and urbanization management?. Sustain. Cities Soc. 1, 45-53. doi: $10.1016 /$ j.scs.2010.08.006

Makonese, T. (2016). "Renewable energy in Zimbabwe," in 2016 International Conference on the Domestic Use of Energy (DUE), 1-9. doi: 10.1109/DUE.2016.7466713

Makonese, T., Chikowore, G., and Annegarn,. H. J. (2011). "Potential and prospects of improved cookstoves (ICS) in Zimbabwe" in Proceedings of the Domestic Use of Energy (DUE), Cape Town.

McGregor, J., and Chatiza, K. (2020). Geographies of urban dominance: The politics of Harare's periphery. ESID Working Paper No. 162. Manchester, UK: The University of Manchester.

Medina, L., and Schneider, F. (2018). Shadow economies around the world: what did we learn over the last 20 years? Int. Monetar. Fund. 36:001. doi: $10.5089 / 9781484338636.001$

Mukheibir, P. (2007). Possible climate change impacts on large hydroelectricity schemes in Southern Africa. J. Energy S. A. 18, 4-9. doi: 10.17159/2413-3051/2007/v18i1a3340

Mukheibir, P. (2013). Potential consequences of projected climate change impacts on hydroelectricity generation. Climatic Change 121, 67-78. doi: $10.1007 /$ s10584-013-0890-5

NASA (2016). The decline of lake kariba. Available online at: https:// earthobservatory.nasa.gov/images/87485/the-decline-of-lake-kariba (accessed June 06, 2020).

NASA (2019). Water levels keep falling at lake kariba. Available online at: https:// earthobservatory.nasa.gov/images/146068/water-levels-keep-falling-at-lakekariba (accessed May, 06, 2020).

Njaya, T. (2015). Informal sector, panacea to the high unemployment in Zimbabwe? case of informal sector enterprises of harare metropolitan. Int. J. Res. Human. Soc. Stud. 2, 97-106.

Paradza, G. (1999). "The retail and service informal sector challenge to urban design in Zimbabwe," in Responsive design and plan implementation, Department of City and Regional Planning, eds A. Brown and C. Davidson (Cardiff: Cardiff University), 20.

Potts, D. (2008). The urban informal sector in sub-Saharan Africa: from bad to good (and back again?). Develop. S. A. 25, 151-167. doi: 10.1080/03768350802090527

REN21 (2020). Renewables 2020 Global status report. REN21 Secretariat, Paris. Available online at: https://www.ren21.net/renewables-report-launch/ (accessed September 09, 2020).

Schneider, F., Buehn, A., and Montenegro, C. E. (2010). New estimates for the shadow economies all over the world. Int. Econ. J. 24, 443-461. doi: $10.1080 / 10168737.2010 .525974$

Spalding-Fecher, R., Joyce, B., and Winkler, H. (2017). Climate change and hydropower in the Southern African Power Pool and Zambezi River Basin: system-wide impacts and policy implications. Energy Policy 103, 84-97. doi: 10.1016/j.enpol.2016.12.009

Sparks, D. L., and Barnett, S. T. (2010). The informal sector in Sub-Saharan Africa: out of the shadows to foster sustainable employment and equity. Int. Bus. Econ. Res. J. 9, 1-12. doi: 10.19030/iber.v9i5.563

Stuart, E., Samman, E., and Hunt, A. (2018). Informal is the new normal: Improving the lives of workers at risk of being left behind, Overseas Development Institute. 
van Vliet, M.ichelle, T., H., Wiberg, D., Leduc, S., and Riahi, K. (2016). Power-generation system vulnerability and adaptation to changes in climate and water resources. Nat. Climate Change 6, 375-380. doi: 10.1038/nclimat e2903

World Bank (2014). Greater Harare Water and Sanitation Strategic Plan: Investement Plan Report. Available online at: https://documents1.worldbank. org/curated/en/982261468196754920/pdf/103574-v1-WP-P126703-PUBLICv1-ZIM-GHWSIP-Report-Final-Volume-I-WB.pdf. (accessed July 05, 2021).

Yuki, K. (2007). Urbanization, informal sector, and development. J. Develop. Econ. 84, 76-103. doi: 10.1016/j.jdeveco.2006.09.004

Zambezi River Authority (2016). Lake Levels. Available online at: http://www. zambezira.org/hydrology/lake-levels (accessed July 29, 2020).

Zambezi River Authority (2019). Zambezi River Authority. Available online at: https://web.facebook.com/ZambeziRiverAuthority/posts/lake-karibaweekly-levels-in-metersthe-kariba-lake-is-designed-to-operate-betwee/ 1453177828162983/?_rdc=1\&_rdr (accessed July 29, 2020).

Zimbabwe Power Company (ZPC) (2018). http://www.zpc.co.zw/data/ media/00000053/2017-ZPC-Annual-Report-Final.pdf (accessed September 08, 2018).

Zimstat (2018). https://www.zimstat.co.zw/wp-content/uploads/publications/ Income/Prices/2018/PDL/PDL_06_2018.pdf. (accessed June 30, 2021).
Zinyama, L., Tevera, D., and Cumming, S. (1993). Harare: The Growth and Problems of the City. Harare: University of Zimbabwe Publications.

Conflict of Interest: The authors declare that the research was conducted in the absence of any commercial or financial relationships that could be construed as a potential conflict of interest.

Publisher's Note: All claims expressed in this article are solely those of the authors and do not necessarily represent those of their affiliated organizations, or those of the publisher, the editors and the reviewers. Any product that may be evaluated in this article, or claim that may be made by its manufacturer, is not guaranteed or endorsed by the publisher.

Copyright (c) 2021 Reid and Simatele. This is an open-access article distributed under the terms of the Creative Commons Attribution License (CC BY). The use, distribution or reproduction in other forums is permitted, provided the original author(s) and the copyright owner(s) are credited and that the original publication in this journal is cited, in accordance with accepted academic practice. No use, distribution or reproduction is permitted which does not comply with these terms. 